\title{
Transforming Passive Receptivity of Knowledge into Deep Learning Experiences at the Undergraduate Level: An Example from Music Theory
}

\author{
Anna Ferenc, Wilfrid Laurier University
}

This article discusses transformation of passive knowledge receptivity into experiences of deep learning in a lecture-based music theory course at the second-year undergraduate level through implementation of collaborative projects that evoke natural critical learning environments. It presents an example of such a project, addresses key features of its design to keep in mind for adaptation to other disciplines, and analyzes its effectiveness through a qualitative study of student reflections. The study yields compelling evidence of enhanced engagement with subject learning, meta-learning and transfer of learning.

\section{Introduction}

$T$ his article discusses transformation of passive knowledge receptivity into experiences of deep learning in a lecture-based music theory course at the second-year undergraduate level through implementation of collaborative projects that evoke "natural critical learning environments" (Bain, 2004). It presents an example of such a project, addresses key features of its design to keep in mind for adaptation to other disciplines, and analyzes its effectiveness through a qualitative study of student reflections.

In his influential book, What the Best College Teachers Do (2004), Ken Bain identifies creation of a "natural critical learning environment" as a fundamental component of effective instruction at the post-secondary level. In such an environment,

people learn by confronting intriguing, beautiful, or important problems, authentic tasks that will challenge them to grapple with ideas, rethink their assumptions, and examine their mental models of reality. These are challenging yet supportive conditions in which learners feel a sense of control over their education; work collaboratively with others; believe that their work will be considered fairly and honestly; and try, fail, and receive feedback from expert learners in advance of and separate from any summative judgment of their effort. (p. 18)

Such an environment activates deep-level learning and metacognitive processing to achieve a "sustained influence on the way the learner subsequently thinks, acts, or feels" (p. 29). Bain acknowledges that this is often accomplished through a "highly authentic" collaborative project (p. 60).

At the core of collaborative projects lies the concept of peer learning, which has been promoted for high-order cognitive and metacognitive 
development for several decades. As pointed out by King (2002), peer learning can enhance mastery of academic content and disciplinary skill as well as foster more complex, high-level cognitive processing. However, adopting this potentially valuable instructional tool comes with a caution that positive results are not automatic and that designing effective peer learning activities is a complex and challenging task (De Lisi, 2002; Palincsar \& Herrenkohl, 2002). Moreover, while studies show that promoting metacognition is critical to learning (Bransford, Sherwood, Vye, \& Rieser, 1986; Coutinho, 2007; Crowe, Dirks, \& Wenderoth, 2008; D’Avanzo, 2003; Hartman, 1998; Pintrich, 2002; Schraw, 1998; Tanner, 2012), it has also been recognized that students may resist thinking metacognitively especially if their background has been limited to passive learning (Gourgey, 1998). Shedding more light on this last point is research indicating that college students typically adopt one of three approaches to their learning in any given course. Some approach their studies as deep learners who want to engage in analysis, synthesis, integration, and re-evaluation of course concepts. Consciously or not, others are either surface learners, who focus on memorizing facts to pass an exam, or strategic learners, who are adept at satisfying requirements only to achieve good grades (Bain, 2012). Such complications present challenges to the design of effective collaborative projects, which in turn begs the question: What are the criteria that contribute to effective project design and by extension to the creation of an effective natural critical learning environment?

Palincsar et al. (2002) imply that the answer to this question may be domain specific as collaborative contexts serve to develop domain-specific reasoning and problem solving. However, my own attempts at designing and implementing collaborative projects have yielded a design that fosters transformation of student learning from passive receptivity into deeplearning experiences, which may be adaptable to disciplines beyond my own. In this paper, I outline an example of such a project and present evidence based on student reflections of its transformational potential to achieve enhanced cognitive and metacognitive learning experiences. I conclude by reflecting on features of the project design that contribute to its effectiveness and offer recommendations for its adaptation as a pedagogical tool.

\section{Contextualization}

The context for my collaborative projects is a required introductory music theory course offered at the second-year level. The course is focussed on chromatic harmony and is open only to music majors. It is the third in a sequence of four term courses that constitute a music theory core, which must be completed by all music majors regardless of disciplinary sub-specialization. The course is lecturebased, as are all courses in the theory core. It builds upon concepts introduced in two prerequisite courses that are completed in a student's first year of study and is in turn prerequisite to the final course of the core. Students enrolled in the course are accustomed to passive receptivity of information, which they typically experience in the first two courses.

\section{Method}

Collaborative projects were implemented into the course to supplement lecture-style delivery of course concepts. Drawing on learning-centred and writingfocused approaches to teaching (e.g., Bean, 2011; Emig, 1977; Holt, 1992; Moon, 2000; Murray, 1982; Paton, 2002), the projects integrate writing-tolearn activities, peer learning and reflection while involving participants not as students, but as aspiring professionals in the field of music theory. Each project explores a particular course topic about which students received instruction in advance through class lectures, textbook readings, and routine problemsolving exercises. Projects simulate authentic experiences in the professional lives of music theorists and require students to work in self-formed groups of two, where one partner assumes the role of a writer 
and the other the role of a reviewer. Partners are required to change roles from one project to the next so that they are exposed to both learning experiences. An example of a project (Project 1) is provided in appendix A. It is the source of student reflections upon which a subsequent study of its effectiveness as a learning tool is based and serves here as a reference for further explanation of project requirements.

The project involves a partnership of author and editor roles and is carefully scaffolded with detailed instructions for its completion and assessment. An opening statement of purpose contextualizes the simulated professional experience and alerts students to important features of the project that may be new to them. The partnership is instructed to produce an essay on a course topic, modulation to closely-related tonalities, for possible publication in a music theory handbook that could be used by music majors at the second-year university level for reference or review purposes. The final product is therefore something that participants would find useful for their own study. Both author and editor produce specific written documents. Given detailed instructions about content requirements, the author is responsible for writing a concise essay of approximately 500 words on the topic of modulation and illustrating it with specific music examples. The essay must be completed by a preset deadline and submitted to the partner editor for review. Upon reviewing and editing the essay, the editor writes a review report that assesses fulfillment of content requirements, presents and compares alternative music examples, and offers recommendations with supporting rationale regarding which examples to include in a final revised version of the essay. Thus, in addition to correcting grammar, the editor also engages with substantive issues in the article. The return of the corrected essay and report to the partner author completes the review by another specific deadline. Thereafter, author and editor consult with each other to reach consensus on a final revised version of their written work that is the best it can be. To complete the project, author and editor write individual statements of reflection on the project experience. Consistent with studies on using reflection as an effective learning strategy (e.g., Ertmer \& Newby, 1996), guidance is provided in the form of questions encouraging participants to think about their learning.

All project work, including formative pieces and the final product, are submitted together for assessment. The project is evaluated according to a rubric accompanying the instructions to disclose the evaluation process as transparently as possible and to clarify quality expectations (Anson \& Dannels, 2002). It is based on a four-point scale that is applied to nine different categories into which the project is segmented for assessment: the quality of project presentation, the quality (but not accuracy) of the author's initial essay, the quality of the editor's review report, the quality and accuracy of the revised essay and of two specific illustrative components that it must contain, the overall understanding of the course topic demonstrated by the project, and individual partner reflections. Students are not assessed in categories for which they have no responsibility. However, for categories into which both partners have input, each receives the same score.

When the course was completed and students were no longer under my supervision, they were invited to submit their project reflections for a secondary qualitative study, which was approved by my institution's Research Ethics Board. The study analyzed the content of reflections for evidence of learning as a function of a participant's project experience as writer or reviewer. Statements about learning were excerpted and organized into four main categories of investigation, each differentiating author and editor roles:

- Statements documenting enhanced engagement with subject learning,

- Statements documenting metacognition/meta-learning,

- Statements on transfer of learning,

- Statements on partnership experience. 


\section{Participants}

The participants are music majors enrolled at the second-year level of a four-year Honours Bachelor of Music program. As music majors, students may be pursuing various disciplinary sub-specializations: performance, composition, music education, music therapy, music history, and/or music theory. From a total pool of 71 students in the second-year level theory course, of which $43(61 \%)$ were female and 28 (39\%) were male, 36 agreed to participate in the secondary study of reflections. The group of 36 participants is comprised of 27 females (75\%) and 9 males (25\%); 14 were project authors and 22 were project editors.

The project grades of these participants ranged from $62 \%$ to $96 \%$ and averaged $79 \%$. Project grades for all students in the course ranged from $29 \%$ to $96 \%$ and averaged $75 \%$. The project represented $15 \%$ of a student's final grade for the course. Final grades for all students in the course ranged from $48 \%$ to $91 \%$ and averaged $74 \%$. Final grades for participants in the secondary study ranged from $55 \%$ to $91 \%$ and averaged also $74 \%$.

\section{Results and discussion}

The analytical segmentation of participant reflections is reproduced in tables below. Excerpts are organized and discussed according to the four categories of investigation. Each category presents author and editor contributions in separate tables.

\section{Category 1: Statements documenting enhanced engagement with subject learning}

Table 1a: Author Statements on Enhanced Engagement with Subject Learning

1. Modulation last year was a source of difficulty for me. On paper, I understood the practice, and when it came to analysis I was passable, but writing them [sic] was quite the challenge. ... Doing this assignment made me seriously look over modulation to closely related tonalities, and as a result I find them in analysis more proficiently. In addition, composing them has become much more effortless than before. However, it also shed some light on another aspect of my musicianship that needs help my ability to hear what is actually on the page.

2. Another surprising challenge I encountered was finding a suitable musical example from my own repertoire to illustrate modulation. It occurred to me just how simply modulation was being exposed to me in the classroom as I sifted through my post-classical period repertoire, attempting to find some semblance of a clearly modelled pivot modulation.

3. I found that I was very often struggling with the idea of where the pivot chord is found or where it should be placed ... I spent time listening to my example and closing my eyes so that I could really hear the pivot into the new key, focus on where it pivots back into the home key and the difference between the modulation and the short tonicization I wrote at the beginning of the chorale. It really goes to show that the more you work on something and the more you practise your basic skills, the more you hear and remember.

4. Finding a piece out of my repertoire that has the exact concept I am studying in theory class also brought the importance and prevalence of music theory to a more personal level. I was able to see in familiar terms why it is that we spend so much time trying to thoroughly understand these concepts.

5. This project was valuable to me in two main ways: First, it clarified and cemented my understanding of modulation to closely related tonalities. ... Second, composing the four-part chorale to demonstrate both tonicization and modulation helped greatly as a refresher not only about modulation but also about the part writing and voice leading process. My editor was particularly helpful in this respect as 
she spent time to review what I had written and to make helpful suggestions for improvement. I asked her to do this while speaking aloud about her thought process and approach so that I could benefit from understanding her methodology.

6. The differences between tonicization and modulation also became clearer to me because I knew how to identify tonicization but I was never sure if I should identify a phrase as having modulated or just tonicizing a new key.

7. I have felt that this project has made a great impact on my understanding of the topics of modulation and tonicization. It has made me have a more thorough understanding of these topics, and writing an example also furthered my understanding. It was interesting approaching how to write the essay, as I am mainly used to writing essays for English or History classes, and I had to learn to be more to the point, and precise with my language ... Even though the way I was explaining the topics may have made sense to me, I needed to constantly check if the explanation would make sense to others without the knowledge I have.

8. I think that the most valuable part of this assignment was the opportunity to explore the topic of modulation independently and in much more depth than usual for theory classes. Having to research and learn something independently fostered a completely different understanding of the material, as it was not just handed down to me by a professor. As uncomfortable as it can be to struggle through a process, I believe that it provides a greater benefit in the end. ... Before this project I did not have a very good grasp of modulation, but after having written my own example of modulation and finding an example of it in my own repertoire, I feel that I am competent in the composition and analysis of modulation to closely related tonalities, and furthermore, I feel that I will actually remember what I learned!

9. The fact that I had to write about the topic with absolute clarity and no vagueness, made me sort out my own thinking about the topic first, and I therefore had a solid understanding of the subject.

10. I think that this project was a very interactive way to test our knowledge of modulation. By asking us to create a document that would be used to teach others required us to be familiar not just with the actual act of modulating within a piece, but also with the terminology and terms used for instruction. I feel that this greatly enhanced my understanding of the topic, because learning the material and then having to teach it are very different experiences.

11. Before doing this assignment, I did not know what a closely-related key was, nor did I know how to identify it. I was also having trouble understanding how a pivot chord worked and how to determine one. I did not know how to properly modulate. Now I am able to give a quick step by step run down of the basic process of modulation to a closely-related key. I am also able to do a proper analysis of a modulation after having been corrected by the editor.

12. This was the first essay of [sic] a music theory topic I had ever written... This in itself was a challenge. What kind of language should I use? Is this the correct terminology? How do I make my point clear? These questions kept circulating in my brain simply because this is very new to me. ... The primary difficulty I came across was in the writing of the 8 bar phrase. This has never been my strong point, but it forced me to think about every chord I was writing and how I was going to analyze it. In the end, [my partner] and I decided that his work was more effective and we were to put that one in the final essay, but I was still proud of the work I, personally, had done. I think that I need to write all my compositions, from now on, with this kind of thought process; everything is an assignment and must be done to perfection. 
Table 1b: Editor Statements on Enhanced Engagement with Subject Learning

1. I found this project to be very helpful because it allowed me to work with a partner and exchange ideas about a topic we have discussed in class. This enabled me to see modulations from a different, more "real" perspective. It also helped me to crystallize my comprehension of the subject matter in my thoughts, making it more concrete and thus simpler to comprehend.

2. I found writing the essay allowed me to really understand what I was writing about, and to put it in terms that will help me further understand for review. By writing about modulations, instead of reading an abstract overview, I really had to understand every detail in order to articulate and edit correctly.

3. While editing the original essay, I was able to reinforce knowledge about the topic. Going over the author's work and looking at every aspect in detail made me think about the concepts and how I would best describe them to another student. Put in the position of an expert or teacher, I had to be careful about describing and writing with clarity, which meant that I had to know the concept very well. ... When I looked over the author's example from the repertoire, I commented that I thought it would be confusing to a reader to see other accidentals in the music, other than the one added for the modulation. When I looked at it again, I realized that these accidentals were just part of the applied chords in the piece. This taught me to watch for applied chords more carefully and showed me to distinguish what I think might be the beginning of a modulation from applied chords with chromatic pitches. I also learned to more readily recognize a modulation.

4. I found this [project] very helpful as an exercise in critical listening, analysis, and judgement. ... It required me to develop a deeper understanding and knowledge of the subject of modulation than I had acquired through the homework assignments.

5. Although I had paid attention in class and done all the work that was assigned based on modulation, editing an essay written on the subject in detail tested my knowledge on the next level.

6. I thought I knew as much about the topic as the author as we are both in the same theory class. What I learned was a more solid feel for the concept of modulation by editing her explanation, by playing her created music example and going over her notation, and by creating my own chorale-style example. It's easy to criticize someone else's efforts, but when you actually go through the same exercise, you realize the difficulty of the assignment. ... Finding the exact descriptive words became an important joint objective, and a useful exercise for future writing of this sort ... by going over the author's explanation of modulation, it clarified my own idea of what the explanation should be. ... Going through someone else's explanation forced me to really analyze what I knew or thought I knew about the topic, and the process of creating an example, and writing an explanation that would teach someone else, greatly enhanced my own knowledge.

7. I learned [that] there can be more than one right answer or one right way to write a paper. ... While the information may not have been new, I did not know it well enough to recall everything without prompting. I am glad I have had this opportunity to relearn this material and display my knowledge.

8. This project was the first time that I had to write about theory, instead of just doing theory exercises. It was a beneficial project for my learning because in order to write about and describe modulation and tonicization, I found that I really had to fully understand the ideas first.

9. Looking at what my partner did and comparing it to mine was very eye opening in the sense that I never would have thought to do certain things that way. Thus expanding my horizons and thinking about theory differently [sic].

10. Although we briefly touched on these subjects in first-year theory, through this exercise the concepts have been solidified and I have learned how to easily recognize and compose modulations and 
tonicizations, and I can clearly differentiate one from the other. I can now identify (visually and aurally) a true modulation ... I also have a better understanding of extended tonicizations ... I now know how to properly label single and extended tonicizations. ... I felt that the author misunderstood and misinterpreted a lot of information regarding the subject of modulation and closely-related tonality, and as a result the essay didn't make sense. To remedy this issue, I had to clearly communicate in my report and in person with my author to review and ensure that he understood the material and knew why his examples and/or explanations wouldn't work in the context of this essay.

11. This project was a useful learning tool because in order for me to properly correct someone else's work I had to fully understand modulation myself. I enjoyed reading the author's essay because it explained modulation in a simpler manner than the ... textbook, making it easier to understand. Through the editing process I had to use my critical thinking skills in order to make suggestions for how to make an already good essay better ... I also liked having to find an example of modulation in repertoire relevant to us as performers. It made me realize how common this phenomenon is, yet how little I thought about it when playing pieces.

12. The experience of editing a theory essay has been an enlightening one. I realized that an editor has to be analytical, looking for inadequacies, and giving feedback to make the essay even better. It is interesting to give constructive feedback in this setting, because I usually never participate in giving feedback in other settings like master class or chamber music class.... I realized that I really had to know about the material beforehand so that I could accurately review the essay.

13. I found this assignment to be an interesting one. It made us think outside our comfort zones; usually one would not write an essay in theory class, and talking about this subject in such a way shed a kind of new light on the topic. For me, at least, this topic was always semi-hazy, but after working with a partner and actually thinking about what I was writing, it really helped me better my understanding of modulation vs. tonicization. ... I had never fully understood these concepts fully [sic], probably because I never attempted to learn them to the best of my ability. I'd had an idea of what these terms "modulation" and "tonicization" meant, but I never did well on tests. Now that this project has been complete, I'm confident that I now know how to use these terms properly.

14. I feel that this project was valuable because it forced me to edit someone else's work, which in turn made me reflect on how I understand modulation and tonicization. Also looking at [my partner's] 8 bar chorale and example in his repertoire made me really look past the notes and look deeper into the music to find out if he analyzed it correctly and did proper voice leading. Overall...this project did deepen my understanding of modulation and tonicization, and working with a partner can often clear up any misunderstandings of the material and solidify what we are learning.

15. Despite my knowledge of modulation, I had very little experience picking it out within my repertoire at the pivotal point. But, through this project and study, it has become more obvious to me where pivotal moments and modulations occur.

16. I found this project to be very helpful. It made me more engaged with my work and helped me understand modulation to its fullest. I feel as if there is nothing about modulation that I don't now know.

17. Being the editor was definitely much more difficult than being the author. While the author could write about what he already knew, I found that I needed to be more familiar on the topic than the author in order to be able to identify all the errors in the essay. In all, I had to spend a few hours reviewing modulating sequences and all the details about tonicization and modulation in general. Even so, the example which the author presented turned out to be quite controversial because it did not fall 
into the definitions of tonicization and modulation as defined in class. What I learned is that there are very specific circumstances in music theory where an "educated guess" of sorts is necessary.

18. This project reinforced my understanding of modulation and closely related tonalities. I believe that making my own chorale example, which included modulation, and searching through my repertoire for a suitable example of modulation were most valuable to me in this project. This is because I have not composed a piece with modulation in it before and I have not analyzed any of my repertoires that closely before. After doing so, I now realize how many of the common idioms and progressions are in my pieces.

19. Declaring what needed to be changed was tough because sometimes it was hard to tell just what did not sit right about how an idea was presented. Once the flaw had been determined, it was up to me to decide what would be more suited to get the idea across. In writing an explanation of music theory, it is very important that words and definitions are clear. In deciding the most effective way to explain something, it ensured that I had to understand the concept and its definitions, in order to be deliberate with my words. ... In going through this process, I discovered that in a specialized topic such as theory, the editor must be equally, if not more knowledgeable than the author. This is a collaborative process, and the editor can only recognize what is wrong and missing if he or she has a deep understanding of the subject ... I think...the product we came up with was more successful than either of us could have achieved on our own.

Across both writer and reviewer roles, statements in this category include comments on applying or synthesizing knowledge, assessing adequacy of skill or knowledge to fulfill project requirements, creating compelling components of the project and evaluating the project's final product, all of which reflect activation of higher-order cognitive skill. Participants express acquisition of greater clarity of subject matter or enhanced proficiency of required skills, recognize gaps in learning and misconceptions, report steps taken to remedy them, discover limitations of the project's topic, and appreciate the relevance or value of studying it. They describe encountering difficulty with writing, editing, analyzing, creating project components, and working hard to overcome them. The statements show that students experienced an active participation in the process of learning that led to an "understanding" of subject matter described variously as "thorough," "solid," "cemented," "enhanced," "reinforced," “on the next level," and "deep." Often, the writing-to- learn and peer learning components of the project are credited with fostering this result.

Tables $1 \mathrm{a}$ and $1 \mathrm{~b}$ together show that comments of $86 \%$ of total participants (31/36) report such enhanced engagement with subject learning. More remarkable is the equally proportioned distribution of this result between writer and reviewer roles: $86 \%$ of authors $(12 / 14)$ and $86 \%$ of editors (19/22) document a more thorough understanding of subject matter as a result of participation in the project. Since the author role in this project is initially responsible for producing an explanatory product, a high score in this category may be expected in that role as predicted by research on learning in peer groups. It indicates that "giving such explanations improves the comprehension for the individual doing the explaining" (King, 2002, p. 36). In this case, the equally high score in the reviewer category suggests that the explanatory responsibility built into the project's editor role is equally and effectively balanced with that of the author. 


\section{Category 2: Statements documenting metacognition/meta-learning}

\section{Table 2a: Author Statements Documenting Metacognition/Meta-Learning}

1. As someone who is strongly considering music education as a career path, I found that attempting to teach such an essential aspect of music as modulation brought to light the difficulty of expressing my understanding of the topic into words that could easily be understood by my peers. I truly did find explaining modulation in writing challenging, not because of my own lack of understanding of the subject, but because of the difficulty in organizing my thoughts and making them easily accessible to others. I believe that this can be attributed to my apparent learning style consisting of simply adhering to the rules of any practice with no need of understanding them. Despite these issues, there is no doubt that overcoming them solidified my understanding of modulation.

2. I have learned that the more work and time I put into something, the more prepared and relaxed I feel about it. Instead of leaving something to the last minute, like much of my past schooling, I did things ahead of time and prepared myself for the deadline. I learn well when I'm not crunched for time (go figure) and it was a nice thing to finally learn with this [project].

3. This has been an invaluable project because it has enabled me to understand what it takes to work with another person on a piece of work I created, and to be able to listen to the criticisms and suggestions with an open mind and an attitude to ameliorate my future work.

4. What was reinforced to me during this project was the hands-on nature of my learning style. Reading texts or other sources is necessary but not sufficient for me to truly understand a topic... Without question, my learning was increased through my interactions with my editor.

5. This assignment helped me realize that I benefit a lot from collaborative work. Once [the editor] had edited through my assignment all of her suggestions to create more clarity in my writing made a lot of sense. Collaborative learning helps me organize my thoughts and evaluate how I am articulating my thoughts because often, many things that seem clear to me are not as clear to a reader so the editing process was very beneficial.

6. Some other notable thoughts gained from this process are that I learn better by explaining things to other people than by merely reading up information on my own. When I am teaching someone else...I feel the need to be more knowledgeable and accurate about that topic than if I were just reading up on it on my own.

7. This project really taught me the impact that one's attitude can have on the completion of a task. Theory has been a struggle for me over the past year (thus it is not my favourite subject), which made me anxious about this project. When I realized that as a piece of writing (which I enjoy), this assignment had real potential to help me understand the concepts and possibly even raise my mark in theory, it became easier to work on. Once I got my mind around the challenges I have faced in theory I even began to enjoy the assignment a little bit. ... For me, this assignment really emphasized the learning process - how you learn is just as important as what you learn. The project enlightened me on much more than just modulation to close-related tonalities.

8. Finally, I also learned that an assignment like this is an excellent way for me to study because it requires me to be so familiar with the material that I am dealing with that I could instruct someone else. This ensures that I have thoroughly grasped the material, and that I am well prepared for any assignments or testing of the material in class. After the completion of this project I felt very well prepared and well-equipped to complete any up-coming assignments. 
9. I discovered that I learn a new topic best through the use of metaphor or simile. Being that this essay was to potentially teach the topic to students at my level, I thought including a metaphor in my essay would be a valuable tool. This also made it easier for me to write the essay, because I kept referring to the metaphor, which helped aid and solidify my learning.

10. Working on this [project] helped me learn many things about my own learning process. I learned that when I am given a task, until I begin engaging in the research topic, I will be flustered and overwhelmed by the task. This is mainly because I will not know where to begin. I have to remember to begin at square one. I must therefore focus on trying to answer the first question. In order to answer the first question, first I must read about the topic. Reading, however, is only half the battle. In order to actually comprehend what I am reading, I must thereafter ask myself questions such as: "What did I learn from this? Can this concept be defined in a different way? How can I apply what I learnt in my work?" In order to broaden my knowledge, once these general questions have been answered, I must also be able to construct intelligent questions related to the topic. This surely supports the statement that "learning requires one to ask questions".

11. I allowed myself to think in a different way: explaining what I know to others clearly and effectively. The information I had was not for my benefit but for other "students." Perhaps it is this kind of thinking I need to use for added clarification of my own knowledge, because I found it to be a very useful tool.

12. I learned working together makes the best results. I learned that having a different opinion on anything (not just writing) can truly make you see something you never would have before. I think the satisfaction I got here is something I rarely get when working on a paper by myself.

Table 2b: Editor Statements Documenting Metacognition/Meta-Learning

1. Reflecting on this entire project has shown me how valuable it has been to my learning process ... They say that you never learn anything as well as when you have to teach someone else, and it certainly held true in this assignment. It really was a "learning" experience!

2. Just like discussing a subject with a partner, writing is definitely a great tool in studying and clarifying your thoughts. It not only forces you to put down on paper a simple and explicit ideas [sic], it also allows you to clearly see where your partner is standing and where your points of view differ. Oral conversations often have a grey area which written documents don't. ... I found that my theoretical knowledge of a subject is often stronger then [sic] my ability to apply it well. This [is] not so much because of lack of knowledge, but more so because of lack of practice. This is perhaps one of the most important things learned from this project; theoretical knowledge must equally and evenly balance the ability to apply it. Those two go hand in hand, and both draw from each other.

3. I much preferred to do this theory assignment than multiple drills and tests as we did in first year theory classes. By doing projects, I'm able to use resources and work things out at my own pace, and figure out what I understand and don't understand in detail. ... I did not learn about my learning style, because I already know that researching and figuring out the "puzzle" at my own speed is the best way I learn, but this project reinforced my past experiences.

4. In completing the steps of the [project], I learned that I need multiple sessions of thinking and dissecting a topic to know it thoroughly. I cannot learn a complex topic in one large amount of time. I would much rather learn by giving myself smaller, but more amounts of time to look at a topic. This reinforces the learning for me and is much more effective than trying to understand it all at once. Through the editing process of this project, I have been able to learn about concepts in music as well as 
my preference for learning styles. It has been useful as a way to make sure I understand modulation and tonicization, while also learning about myself.

5. This was the first time that I had to write or edit an essay relating to theory. I learned a few things from the experience. First, explaining a concept in words confirms your knowledge of the subject. It is then easier to apply the concept to the practice exercises or in your repertoire. Also, I learned that editing someone else's work was teaching me to be more critical of my own writing.

6. I now realize that I need to spend more time reviewing notes and textbooks before starting similar assignments, and spend more time planning overall.

7. I found it to be a valuable way to review or "study" for theory because I am able to put what I learned into practice and also apply it to my own repertoire. ... I found that these project-type assignments help me better my understanding for concepts. Also, I find them more interesting than basically studying the topics straight from a textbook.

8. Through editing [my partner's] essay, I found little things she could write to make the essay even better. This also got me more involved with how to understand and explain things to myself.

9. I learned that the act of writing and composing is a very effective vehicle for learning.

10. This [project] also showed me a lot about my own learning - that I learn through practice and review.

11. This project made me think in a new way and it was a great way to learn.

12. The hardest part of this assignment for me was writing the chorale because I find it difficult having to create something out of nothing. It feels very intimidating to start with just an empty page and no voices or figured bass to guide me, but I know every time that I write like this I not only improve my voice leading skills, but also my conceptual skills.... There are lots of different types of learners and I like that this project offers lots of different opportunities for students to cement their foundation of modulation in different ways; whether it be for those who prefer analysis (the example from the repertoire), composition (the chorale), or language and writing (the essay). I am glad I had the opportunity to do this project because now I feel far more comfortable with modulation.

13. The assignment did teach me that sometimes I don't know material as well as I think I do.

14. What I learned about my own learning is that I cannot focus for a long period. So I would do this project in many sections and kept looking over what I was trying to fix/write.

15. I also enjoyed working with a partner because it was very intriguing to me to see how others perceive the material we are learning in class, and how they go about explaining it. It gave me a different perspective on how I thought about modulation, and I believe I will now be more open minded and think of all the different possibilities that can apply to a topic as I continue on in the course. ... I have always been very hesitant about actually applying what I know to create something of my own, however I learned that it is actually very useful to do so and it ingrains the knowledge into your brain even more so. ... I also discovered that I learn better when bouncing ideas off of a peer or hearing how they interpret a topic. It also gave me more confidence and was a very encouraging process for me. All in all I really enjoyed this project. ... It showed me how much I have grown even over just this term when working on theory.

Tables $2 \mathrm{a}$ and $2 \mathrm{~b}$ together show that reflections of $75 \%$ of total participants (27/36) document metacognitive development or meta-learning. This respectable score speaks to the promotion of highlevel cognitive processing facilitated by the project. Writers and reviewers report discovering learning through writing and learning through teaching, learning about individual learning styles, learning about how to learn with and from others, learning how to take responsibility for learning, and discovering the role that attitude plays in learning. Consistent with findings in Mugny and Doise (1978) 
and King (2002), participants describe learning through resolution of socio-cognitive conflict and they recognize value in negotiating a collaborative construction of knowledge.

Again $86 \%$ of authors (12/14), but only $68 \%$ of editors $(15 / 22)$ contributed comments to this category. This discrepancy suggests that the project has the potential to illicit a stronger metacognitive response from participants as writers rather than reviewers. From an instructional point of view, it is therefore prudent to implement as least two such projects into a given course and to require partners to change roles from one to the next.

\section{Category 3: Statements on transfer of learning}

Table 3a: Author Statements on Transfer of Learning

1. After completion of this project, I found there to be many valuable lessons learned from it. Firstly, time management was a crucial element because, not only was my work dependent on being handed in on time, but my partner was dependent on me. Working as a member of a team is a part of life that will always happen, thus applying this project to developing time management skills for the future [sic]. ... Secondly, communication was a key factor for this project's success. [My partner] and I were constantly in touch about when the other would be receiving work or which modulation examples should be used. This, too, made us an effective team when working together. This is a quality that can also be carried out into other aspects of life in the future. ... Overall, I found the [project] to be a great learning experience. It opened me up to a new way of writing - both essay and musical composition. This will be extremely helpful to me throughout my university life and on.

2. I learned more about using musical terms in my writing to articulate exactly what I was referring to which is a helpful tool for future writing assignments as well as being able to communicate with fellow musicians about something within a piece of music.

3. ...My editor brought up a good point, mainly that when writing formal essays I tend to use the word, "however," far too often. That's something I'll have to keep in mind. I'm certainly happy that this has been pointed out to me now, before any other papers are due.

Table 3b: Editor Statements on Transfer of Learning

1. To me, gaining a thorough understanding of the concepts of modulation, tonicization and closelyrelated tonalities over the course of this project was incredibly valuable as a music student. I feel that this information has helped me to better comprehend the music that I am listening to, studying and performing.

2. This project also made me more aware of compositional techniques used in my own repertoire. When I was asked to find an example of modulation in my own repertory, I had to consciously listen to the pieces I was familiar with and understand what was occurring in the underlying harmonies. As a result, I am now able to find the places where modulation occurs in a piece and consider the appropriate musical interpretation.

3. I can see how these theories work in the pieces I sing and perform regularly. ... Overall, I think this project was definitely valuable to my learning because it was such a different approach to learning and allowed me to apply what I was learning to other parts of my studies.

4. It has become very clear to me that I have to improve my writing skills. If I want to be a theorist - I'll have to learn to communicate ideas with writing. 
5. Because we were using three different ways to communicate our knowledge about the subject, through writing, composition, and analysis, we also became knowledgeable in three ways to teach the subject. This aspect of the subject was very valuable to me, as I am very interested in the different ways of teaching for different learning styles, known as differentiated instruction.

6. During the process of this project, I truly learned the complete myth behind the common, yet completely false phrase 'those that can't do, teach'. This phrase is spoken so many times, but is absolutely untrue. As a student of music education, I found this project helpful to think in terms of creating a lesson plan, or a handout sheet for students. When forced to write all you know about a certain topic, you start to become somewhat of an expert in that field, and more of an expert as you teach what you know to others.

$21 \%$ of authors $(3 / 14)$ and $27 \%$ of editors $(6 / 22)$ together constitute $25 \%$ of participants $(9 / 36)$ who recognize possibilities or opportunities to transfer learning from the project to other academic endeavours, to training in music performance or other areas, or to development of life skills. It is interesting to note that, although students were directed to derive information from their own music repertoires and include it in the project, only three participants $(8 \%)$ in the editor role commented on the possibility to transfer learning out of the theory course into performance studies. Instead, most participants credit this activity with enhancement of subject learning; that is, with transferring knowledge of performance repertoire into the theory course. This result suggests that a targeted effort must be made to teach for a specific type of transfer in order to achieve it significantly.

The remaining comments in this category that speak to other opportunities for transfer of learning are nevertheless noteworthy. Their presence proves that the project's design fosters an engaging learning environment in which cognitive, metacognitive, and affective learning components interact to stimulate the surfacing of such relevant and deep-learning outcomes (Gourgey, 1998).

\section{Category 4: Statements on partnership experience}

\section{Table 4a: Author Statements on Partnership Experience}

1. My editor was particularly helpful in this respect as she spent time to review what I had written and to make helpful suggestions for improvement. ... The only significant difficulty I encountered was in getting enough of [my editor's] time to focus on and to complete this assignment. It was a particularly busy period for her. My approach was to provide frequent reminders (in person and via email) and to maintain a patient and positive attitude. This approach yielded results and I feel we have worked together well to generate a good product. ... Without question, my learning was increased through my interactions with my editor.

2. During the writing process I was reminded of how helpful it is to have someone you trust edit your work. My editor did not make a huge number of changes to my work, but her comments were very insightful, and those few changes made a big difference in the way the information fit together.

3. [The partner] and I were constantly in touch about when the other would be receiving work or which modulation examples should be used. This, too, made us an effective team when working together. ... The remarks and suggestions that he [the editor] made on my first copy of the essay truly helped me.

4. I learned to work with an editor, and to take criticisms my editor brought up into consideration for my final work. ... I learned that some of the criticisms I received initially seemed arbitrary, but upon 
further consideration, they were valid and made the final edition more solid and left less room for dispute.

5. I also enjoyed the last stage of this project when we were allowed to meet with the editor and share our thoughts because it helped me realize where I can improve and how to make my thoughts clearer to a reader which is valuable in any writing assignment.

6. I also learned to take suggestions from a peer, something that I have not always been open to in the past. My editor definitely had some good suggestions in terms of clarity and wording.

7. I have also learned more about the process of working with a partner, and being able to coordinate with them. Learning to work with others is a necessary skill, and the ability to each [sic] communicate with each other is mandatory. My partner and I communicated excellently with each other, and from this, I realized how necessary it is to be able to trust and be open with your partner in assignments. Every group project continues to hone my skills at working on a team, and I felt this assignment only helped to strengthen my ability to work coherently in a group setting.

Table 4b: Editor Statements on Partnership Experience

1. I found this project to be helpful because it allowed me to work with a partner and exchange ideas about a topic we have discussed in class. ... Time management becomes more complex when working with a partner, and so scheduling and deadlines become much more important. The multiple due dates definitely helped avoid a rush close to the final deadline, and are a thing to keep in mind for future longer term projects.

2. Mostly, I valued having [the author] as a partner; because of her I now understand this topic fully. It's interesting to note what a person can learn when paired with their peers. ... Working in pairs has never been my favourite activity, but it was more enjoyable than experiences I've had in the past - I think because we each did our work separately, but then collaborated for the finished product. Because we worked individually on our portions of the assignment, both of our personalities and writing styles are incorporated which makes the final result much more rewarding.

3. I am a student who prefers to work on my own. This project was a good exercise in working together with a partner and respecting each other's time and effort in order to obtain good results.

4. However, it is difficult to pick apart the work of one of your classmates. I found it personally difficult to word my editing and suggestions, on top of the thought that I'm judging the work of a peer. As someone who struggles with written communication, I also gave my author thoughts in person having to explain the limited explanation in places.

5. During the process of completing this project, there were a couple of things that I deemed valuable to me, such as the essence of teamwork. I have found that getting your part done on time is crucial to the trust you and your partner share. Also, communication was a big aspect of what made us a good team. For example, even if I had finished my part on time I still had to communicate where and when I could give it to her thus making sure I'd get it to her at a certain time. As well, discovering what can be learned from your partner. By this I mean seeing work done by others on the same subject as you. ... I definitely learned a lot by reading [the author's] first draft of the essay. Not only did it impress me by writing style but by the flow and effectiveness of what modulation and tonicization was. I also learned that I know a lot more about this topic then [sic] I previously thought.

6. A challenge for me was trying to clarify the authors' [sic] thoughts in her writing, without completely re-writing it in my own words. I did have to add a few sentences, but they were well received, and made our project better as a whole. 
7. This project was of value to me through the editing process and consultation with my partner ... Some difficulties we encountered as a group were getting together and discussing the project as we both had very different schedules and weekend plans. We overcame this by having a live video chat meeting online to discuss any problems or concerns before finishing the final copy of the essay. This worked very well and we were able to clearly communicate through the video.

8. As "editor", it is natural to separate myself from the work being presented and associate it as the work of the "author". However, I think in order to be most successful, it must be seen as a collaborative process, and that it is "our" work. I felt that this concept could have more effectively been achieved if we spent more time together discussing the process. However, I think the process we used was time efficient.

9. I felt that the author misunderstood and misinterpreted a lot of information regarding the subject of modulation and closely-related tonality, and as a result the essay didn't make sense. To remedy this issue, I had to clearly communicate in my report and in person with my author to review and ensure that he understood the material and knew why his examples and/or explanations wouldn't work in the context of this essay. We also used communication skills to determine how to appropriately re-write the assignment in a manner that was reader-friendly and factually accurate.

10. One of the difficulties I discovered in the engaging of this project was that my idea of how to explain closely-related tonalities was not exactly that of the author's, although both were technically correct. It was an important exercise to go through the "give and take" that is a necessary part of a joint creative process - it can be hard to work with a partner. I felt my music example provided a clearer explanation of modulation as her example had some errors, and she was quick to agree with me. Of course, what really helped is that we are such solid friends and we both had the same goal: to create the best article on modulation for a music theory handbook possible! I have great respect both for her as a person, and for her intelligence, so the idea of compromise and collaboration was easy to come to for both of us.

11. What I found difficult about this project was editing my peer's work. I am always very doubtful in myself so when it comes to editing it intimidates me to make corrections or write down my input. Although I was worried that my input would be irrelevant and incorrect I wrote it all down and then discussed it with the author. Having the author was actually very reassuring and helped me realize that I was able to apply my knowledge and be correct as well.

12. I also learned that working in a group can be very rewarding. My partner was eager to get together, open to my suggestions but not afraid to put forth her own ideas, and willing to compromise, and expressed a genuine interest in the topic. I was concerned about working with a partner as I have had problems with group projects in the past, but my experience this time has been very positive. I felt like I was able to communicate effectively with my partner and produce an acceptable product.

In their reflective statements, $50 \%$ of authors (7/14) and 55\% of editors (12/22) comment on partnership experiences. The comments highlight helpful collaboration, effective teamwork, excellent communication, appreciation of internal project deadlines, forging trust, and mutual respect. Participants acknowledge difficulties or challenges with scheduling, time management, and learning to accept criticism, but at the same time express satisfaction with creative solutions or perseverance to overcome them. No mention is made of any negative partnership experiences.

The absence of any negative comments in this category may appear curious at first, but the overwhelmingly positive tone across both writer and reviewer roles is consistent with and supports statements in the previous three categories that credit partnership experiences for enhanced engagement with subject learning, meta-learning, and transfer of learning. There are several contextual and design 
reasons that may account for this result. In the first place, music majors at my institution form a fairly cohesive group, especially during the first two years of core studies in the program. Many, though not all students, interact with each other in other common classes and ensembles. Therefore, it could be expected that partnerships formed by students themselves for purposes of this project would have a higher probability of being well-matched. In addition, there are features of the project's design that intentionally support productive partnership, which are addressed in the conclusion below.

\section{Conclusion}

The reflections of participants in this study describe a rich tapestry of learning experiences at an introductory undergraduate level demonstrating that the project through which they are achieved is a robust pedagogical tool. The final product that is produced (the revised essay) is generally much improved in quality over its initial version as peer review and collaborative learning processes correct most errors without instructor input. In my experience of implementing various versions of the project described here, the effectiveness of this particular iteration is a function of its design. In its current form, the integration of carefully structured writing-to-learn activities, peer learning, and reflective practice produces an environment capable of transforming students into disciplinary practitioners who experience deep learning through collaborative engagement.

The project may be adapted to other domains in which similar disciplinary partnerships operate. When doing so, I recommend adhering to the following criteria that contribute to effective project design:

1. Provide as much project scaffolding as possible and do not take anything for granted. Especially at an introductory undergraduate level, students require very detailed technical instructions to fulfill an academically demanding assignment and produce a compelling final product. When instructions are sufficiently detailed, students can rise to the challenge of meeting high expectations.

2. To achieve productive peer learning, it is insufficient to limit the reviewer only to editing a writer's work. If this is the case, the partnership of writer and reviewer risks breaking down because the workload is unbalanced. Reviewers must be equally engaged in research and writing processes.

3. Internal deadlines for formative writing-tolearn components of the project are crucial and assessment should take into consideration whether or not deadlines were met as reported by participants. The instructor may choose to recommend due dates as a guideline to be adjusted by partners in mutual agreement to better suit their schedules.

4. Formative writing-to-learn components (i.e. the author's original essay and the editor's review report) should be included in complete project assessment. Inclusion of these components builds individual accountability into the project design. The more attention partners give to their individual contributions, the more productive and potentially transformative their learning experiences will be.

5. Guided individual reflections are important project components. As discussed in literature on reflection (e.g., Ertmer \& Newby, 1996), such statements are the vehicles through which students make sense of their learning, take responsibility for it and potentially connect it to other learning. Reflection statements also provide the instructor with valuable feedback on student learning experiences.

6. Rubrics are effective project assessment tools. It is beyond the scope of this paper to discuss rubric designs, but it is important to note that the accompanying rubric for assessment reproduced in appendix B allows for equitable individual scoring within the group 
project, streamlines the marking process, and is a guide to agreement if more than one grader is involved. The rubric should not be withheld from students, but rather disclosed with project instructions to define quality expectations and facilitate transparency of the grading process.

As shown by the analysis of student reflections, the design of this collaborative project promotes enhanced engagement with subject learning and meta-learning and stimulates transfer of learning. It is a vehicle through which students at an introductory undergraduate level of study can engage genuinely in productive peer learning experiences that develop self-efficacy and enhance motivation for learning. The integration of the project into a lecture-based course can effectively transform passive receptivity of knowledge into deep learning experiences.

\section{References}

Anson, C. M., \& Dannels, D. P. (2002). Developing rubrics for instruction and evaluation. In D. Roen, V. Pantoja, L. Yena, S. K. Miller, \& E. Waggonner (Eds.), Strategies for teaching firstyear composition (pp. 387-401). Urbana, IL: National Councils of Teachers of English.

Bain, K. (2004). What the best college teachers do. Cambridge, MA: Harvard University Press.

Bain, K. (2012). What the best college students do. Cambridge, MA: Harvard University Press.

Bean, J. C. (2011). Engaging ideas: The professor's guide to integrating writing, critical thinking, and active learning in the classroom ( $2^{\text {nd }}$ ed.). Hoboken, NJ: Jossey-Bass.

Bransford, J., Sherwood, R., Vye, N., \& Rieser, J. (1986). Teaching thinking and problem solving: Research foundations. American Psychologist, 41, 10781089. http://dx.doi.org/10.1037/0003066X.41.10.1078
Coutinho, S. A. (2007). The relationship between goals, metacognition, and academic success. Educate-, 7(1), 39-47. Retrieved from http://www.educatejournal.org/index.php/ed ucate/issue/view/23

Crowe, A., Dirks, C., \& Wenderoth, M. P. (2008). Biology in bloom: Implementing Bloom's taxonomy to enhance student learning in biology. CBE-Life Sciences Education, 7, 368381. http://dx.doi.org/10.1187/cbe.08-050024

D'Avanzo, C. (2003). Application of research on learning to college teaching: Ecological examples. BioScience, 53, 11211128. http://dx.doi.org/10.1641/00063568(2003)053[1121:AOROLT]2.0.CO;2

De Lisi, R. (2002). From marbles to instant messenger: Implications of Piaget's ideas about peer learning. Theory Into Practice, 41, 512. http://dx.doi.org/10.1207/s15430421 tip4 101_2

Emig, L. (1977). Writing as a mode of learning. College Composition and Communication, 28, 122-128. http://dx.doi.org/10.2307/356095

Ertmer, P. A., \& Newby, T. J. (1996). The expert learner: Strategic, self-regulated and reflective. Instructional Science, 24, 1-24. http://dx.doi.org/10.1007/BF00156001

Gourgey, A. F. (1998). Metacognition in basic skills instruction, Instructional Science, 26, 8196. http://dx.doi.org/10.1023/A:100309 2414893

Hartman, H. (1998). Metacognition in teaching and learning: An introduction. Instructional Science, 26, 1-3. http://dx.doi.org/ 10.1023/A: 1003023628307

Holt, M. (1992). The value of written peer criticism. College Composition and Communication, 43, 384-392. http://dx.doi.org/10.2307/358229

King, A. (2002). Structuring peer interaction to promote high-level cognitive processing. 
Theory Into Practice, 41, 3339. http://dx.doi.org/10.1207/s15430421tip4 101_6

Moon, J. A. (2000). Reflection in learning and professional development: Theory and practice. London: Kogan Page.

Mugny, G., \& Doise W. (1978). Socio-cognitive conflict and structure of individual and collective performances. European Journal of Social Psychology, 8, 181192. http://dx.doi.org/10.1002/ejsp.2420080 204

Murray, D. M. (1982). Learning by teaching. Montclair, NJ: Boynton/Cook Publishers.

Palincsar, A. S., \& Herrenkohl, L. R. (2002). Designing collaborative learning contexts. Theory Into Practice, 41, 2632. http://dx.doi.org/10.1207/s15430421 tip4 101_5

Paton, F. (2002). Approaches to productive peer review. In D. Roen, V. Pantoja, L. Yena, S. K. Miller, \& E. Waggonner (Eds.), Strategies for teaching first-year composition (pp. 290-301). Urbana, IL: National Councils of Teachers of English.

Pintrich, P. R. (2002). The role of metacognitive knowledge in learning, teaching, and assessing. Theory Into Practice, 41, 219225. http://dx.doi.org/10.1207/s15430421 tip4104_3

Schraw, G. (1998). Promoting general metacognitive awareness. Instructional Science, 26, 113125. http://dx.doi.org/10.1023/A:100304423 1033

Tanner, K. D. (2012). Promoting student metacognition. CBE-Life Sciences Education 11, 113-120. http://dx.doi.org/10.1187/ cbe.12-03-0033

\section{Acknowledgements}

I thank the students at the Faculty of Music of Wilfrid Laurier University who agreed to participate in this study.

\section{Biography}

Anna Ferenc is Associate Professor and Coordinator of music theory at Wilfrid Laurier Universtiy. Her contribution to the scholarhip of teaching and learning is rooted in a passion for undergraduate-level instruction and a research interest in music theory pedagogy. 


\section{Appendix A}

\section{Project 1 \\ Topic: Modulation to Closely-Related Tonalities}

Purpose: Music theorists often write specialized essays for books devoted to a particular topic or meant for a particular purpose. In this assignment, you have an opportunity to experience this professional process as you demonstrate your learning about modulation. The assignment introduces you to disciplinary writing, peer review, and learning through reflection.

General Instructions: This assignment requires that you work in groups of two. Each group consists of an author and an editor. Between you and your partner, decide who will assume which role and then follow the instructions for that role. When completed and ready for submission, this assignment will consist of 7 items:

1. A title page "Project 1: Modulation to Closely-Related Tonalities" indicating the names of author and editor

2. A first version of an essay including a chorale example and a repertoire excerpt

3. A review of the first version of the essay including an alternative chorale example and an alternative repertoire excerpt

4. A revised version of the essay including revised chorale example and repertoire excerpt

5. Reflections of the author

6. Reflections of the editor

7. Rubric for Assessment of Project 1

All 7 items constitute Project 1. Bind them together in the above order when you submit Project 1 for assessment. It will be evaluated according to the accompanying rubric.

Note the following important deadlines:

Deadline for author to submit first version of essay to editor:

Deadline for editor to submit review report to author:

Deadline for submission of completed Project 1:

If you encounter difficulty at any point with this assignment, please contact the instructor. 


\section{Instructions for Partner 1: Author}

\section{Write an essay.}

You have agreed to write an essay on the topic of modulation to closely-related tonalities for a music theory handbook. The handbook is to be used by 2 nd-year music majors for reference or review purposes. The essay you submit must be double spaced, in 12-point font, and approximately 500 words in length. It must be written in your own words. If you use material from any text, you must provide reference in a footnote or endnote. This first version is not a rough draft; rather, it must represent your best possible independent work. You must write this first version of your essay without collaborating with anyone else, even your editor. You may consult with your editor after you receive her/his review report of your essay.

Your essay must include the following information:

1. The title "Modulation to Closely-Related Tonalities," your name and date of submission to your editor.

2. What is modulation? How does it differ from tonicization? In what way is it similar?

3. What does it mean to modulate to closely-related tonalities? Identify closely-related tonalities in major and minor modes.

4. How is modulation to closely-related tonalities usually accomplished and how is it analyzed?

5. To supplement your essay, compose a chorale-style music example in 4/4 time and in a tonality of your choice. The example must be 8 measures long and must subdivide into two 4-measure phrases, each phrase ending with an appropriate cadence. In the first phrase, modulate to a closely-related tonality of your choice. In the second phrase, modulate back to the home key. In addition to the modulations, include at least 1 tonicization in your example. In your essay, refer to it to explain the difference between tonicization and modulation. Provide a 2-level harmonic analysis of your example. Mark pivot chords as required and identify cadences. In your essay, refer to your composed example to illustrate your explanations.

6. Include an example of a modulation within a musical composition. To do this, find an example of a modulation to a closely-related tonality in repertoire you are performing or have performed. In your essay, identify the composer, title of the composition, its home tonality, and the tonality to which it modulates in your chosen excerpt. On the score, identify the home key and analyze the modulation to the cadence in the new key. Identify the cadence. Note: This repertoire example should be no more than 1 page long. If the composition you have chosen is more than 1 page long, provide only an excerpt from your chosen piece that sets the musical context and includes the modulation. Add measure numbers to your excerpt to show its placement relative to the rest of the piece.

\section{Submit your essay to your editor}

Submit the completed first version of your essay to your editor and keep a copy for yourself. 


\section{Revise the essay}

When your editor returns your essay to you, write at the top of the Editor's Review Report: "Received by author on [fill in the date]." Do not alter your first reviewed version in any way as it forms part of the complete Project 1 submission. Consider your editor's comments and consult further to reach consensus on differences of opinion. Revise your essay as needed to create a new second version that is the best it can be.

\section{Reflection}

Having completed revision of the essay, think about what you have learned from this project activity. On a separate sheet of paper under the heading "Reflections of Author," compose your thoughts about this assignment in a few paragraphs in 12-point font. You may use the following questions to guide your reflection, but you need not limit your observations to them:

What was valuable to me in this project?

$>$ What did I learn about the topic while doing this project that I didn't know before?

$>$ What difficulties did I encounter while engaging in this project? How did I remedy them?

$>$ What did I learn from or about writing?

$>$ What did I learn about my own learning?

\section{Instructions for Partner 2: Editor}

\section{Review the essay}

You have asked the author to write an essay on the topic of modulation to closely-related tonalities for your music theory handbook. As editor, your job is to review and edit your author's essay. This involves correcting mistakes, suggesting changes, and writing a review report. To review the essay, you must be sufficiently familiar with the topic. While your author is writing the essay, your responsibility is to search out a modulation excerpt in your own repertoire and to compose your own 8-measure chorale-style music example as described above in the instructions for partner 1 . The review report must be written in essay form, double-spaced and in 12-point font.

Your review report must include the following information:

1. The title "Editor's Review Report," your name and date of submission to your author.

2. The date of your receipt of the essay. Was it submitted to you on time?

3. Does the presentation of the essay comply with expectations? This means:

$>$ Is the essay appropriately titled and does it include the author's name?

$>$ Is it double-spaced and in 12-point font?

$>$ Is all work neatly presented?

If not, point out inadequacies.

4. Is the essay an appropriate length? It must be approximately 500 words long.

5. Is the essay written well overall? Are sentences and paragraphs structured properly? Are there typographical errors in the essay? Identify problems and make corrections.

6. Does the essay explain modulation clearly? If not, suggest clarifications.

7. Does it compare modulation with tonicization correctly? If not, suggest changes. 
8. Does the essay include an 8-measure chorale-style music example that complies with requirements and illustrates modulation? Is the 2-level analysis done correctly? If not, make corrections.

9. Does the essay include an example of modulation in an excerpt from music repertoire? Is the context of the excerpt clear and is the modulation properly analyzed? If not, point out what is incorrect or unclear and suggest changes.

10. Present your own chorale-style music example and repertoire excerpt that comply with requirements and could serve as possible alternative suggestions. How do they compare with your author's music example and repertoire excerpt? Which ones should be included in the final version of the essay? Explain why.

\section{Submit your review to your author.}

Return the corrected essay with your review report to your author. Keep a copy for yourself.

\section{Consult with your author}

Consult with your author as needed to create a revised second version of the essay that is the best it can be. If you and your author have different opinions on certain matters, discuss them until you reach a consensus.

\section{Reflection}

Having completed the revision of the essay, think about what you have learned from this project activity. On a separate sheet of paper under the heading "Reflections of Editor," compose your thoughts about this assignment in a few paragraphs in 12-point font. You may use the following questions to guide your reflection, but you need not limit your observations to them:

$>$ What was valuable to me in this project?

$>$ What did I learn about the topic while doing this project that I didn't know before?

$>$ What difficulties did I encounter while engaging in this project? How did I remedy them?

$>$ What did I learn from or about writing?

$>$ What did I learn about my own learning? 


\section{Appendix B}

\section{Rubric for Assessment of Project 1}

\begin{tabular}{|c|c|c|c|c|c|c|c|}
\hline $\begin{array}{l}\text { Assessment } \\
\text { Categories }\end{array}$ & 0 & 1 & 2 & 3 & 4 & $\begin{array}{l}\frac{\text { Author }}{\text { Points }} \\
\text { earned }\end{array}$ & $\begin{array}{l}\text { Editor } \\
\text { Points } \\
\text { earned }\end{array}$ \\
\hline $\begin{array}{l}\text { Presentation of } \\
\text { Project } 1\end{array}$ & $\begin{array}{l}\text { Not submitted } \\
\text { for } \\
\text { assessment. }\end{array}$ & $\begin{array}{l}\text { The project is disorganized. } \\
\text { Items are missing or } \\
\text { incomplete. }\end{array}$ & $\begin{array}{l}\text { The project is essentially } \\
\text { complete, but some items } \\
\text { are out of order. }\end{array}$ & $\begin{array}{l}\text { The project is complete and } \\
\text { in order, but not all } \\
\text { individual items comply } \\
\text { with presentation } \\
\text { requirements. Some parts } \\
\text { may lack neatness. }\end{array}$ & $\begin{array}{l}\text { The project is complete, } \\
\text { and in order, All items } \\
\text { comply with } \\
\text { presentation } \\
\text { requirements. All work } \\
\text { is neatly presented. }\end{array}$ & & \\
\hline $\begin{array}{l}\text { Author's first } \\
\text { version of essay }\end{array}$ & $\begin{array}{l}\text { Not submitted } \\
\text { for } \\
\text { assessment. }\end{array}$ & $\begin{array}{l}\text { Submitted late to the } \\
\text { editor. } \\
\text { Or, submitted on time, but } \\
\text { is disorganized, incomplete, } \\
\text { and/or poorly written. It } \\
\text { may lack proper paragraph } \\
\text { or sentence structure, or } \\
\text { contain many typos. Music } \\
\text { example may be sloppy or } \\
\text { inadequate. Repertoire } \\
\text { excerpt may be inadequate } \\
\text { or poorly analyzed. }\end{array}$ & $\begin{array}{l}\text { Essay is submitted on time } \\
\text { and is somewhat organized, } \\
\text { but does not comply with } \\
\text { many requirements } \\
\text { regarding content, length } \\
\text { and presentation } \\
\text { expectations. The work } \\
\text { appears to be half-done. }\end{array}$ & $\begin{array}{l}\text { Essay is submitted on time } \\
\text { and is well organized. } \\
\text { Sentence and paragraph } \\
\text { structure is good, but needs } \\
\text { improvement. Content is } \\
\text { complete, but presentation } \\
\text { requirements or length } \\
\text { does not meet } \\
\text { expectations. Music } \\
\text { example or repertoire } \\
\text { excerpt may not comply } \\
\text { with some requirements or } \\
\text { may not meet presentation } \\
\text { expectations. }\end{array}$ & $\begin{array}{l}\text { Essay is submitted on } \\
\text { time, is well organized } \\
\text { and clearly written. All } \\
\text { content and } \\
\text { presentation } \\
\text { requirements meet } \\
\text { expectations. It is } \\
\text { obvious that the essay } \\
\text { matters to the author. }\end{array}$ & & N/A \\
\hline $\begin{array}{l}\text { Editor's Review } \\
\text { Report }\end{array}$ & $\begin{array}{l}\text { Not submitted } \\
\text { for } \\
\text { assessment. }\end{array}$ & $\begin{array}{l}\text { Submitted late to the } \\
\text { author. Or, report is } \\
\text { submitted on time, but is } \\
\text { disorganized, incomplete, } \\
\text { poorly written, and/or } \\
\text { contains incorrect } \\
\text { information. It may lack } \\
\text { proper paragraph or } \\
\text { sentence structure, or } \\
\text { contain many typos. It may } \\
\text { omit suggestion of } \\
\text { alternative chorale example } \\
\text { or repertoire excerpt. It } \\
\text { does not comply with } \\
\text { several requirements } \\
\text { and/or is not helpful. }\end{array}$ & $\begin{array}{l}\text { Report is submitted on time } \\
\text { and is somewhat organized, } \\
\text { but does not comply with } \\
\text { many requirements } \\
\text { regarding content and } \\
\text { presentation expectations. } \\
\text { Alternative chorale } \\
\text { example or repertoire } \\
\text { excerpt are sloppy, contain } \\
\text { errors, or are poorly } \\
\text { explained. Review misses } \\
\text { many errors in essay. The } \\
\text { review work appears to be } \\
\text { half-done. }\end{array}$ & $\begin{array}{l}\text { Report is submitted on time } \\
\text { and is well organized. It } \\
\text { makes several helpful } \\
\text { suggestions. Sentence and } \\
\text { paragraph structure is } \\
\text { good, but some errors or } \\
\text { improvements to the essay } \\
\text { are overlooked. Alternative } \\
\text { chorale example or } \\
\text { repertoire excerpt are } \\
\text { almost error-free. Report } \\
\text { content is mostly complete, } \\
\text { but presentation } \\
\text { requirements may not } \\
\text { meet expectations. }\end{array}$ & $\begin{array}{l}\text { Report is submitted on } \\
\text { time, is complete, well } \\
\text { organized and clearly } \\
\text { written. All or almost all } \\
\text { errors in the essay, } \\
\text { chorale example and/or } \\
\text { repertoire excerpt have } \\
\text { been corrected. } \\
\text { Overall, a helpful review } \\
\text { that meets } \\
\text { expectations. It is } \\
\text { obvious that the review } \\
\text { matters to the editor. }\end{array}$ & N/A & \\
\hline $\begin{array}{l}\text { Final version of } \\
\text { essay }\end{array}$ & $\begin{array}{l}\text { Not submitted } \\
\text { for } \\
\text { assessment. }\end{array}$ & $\begin{array}{l}\text { Essay explains modulation } \\
\text { poorly or does not include } \\
\text { required information. } \\
\text { Sentence structure may be } \\
\text { improved, but essay still } \\
\text { contains most of the same } \\
\text { content errors present in } \\
\text { the first version or includes } \\
\text { new errors. Shows little } \\
\text { improvement. }\end{array}$ & $\begin{array}{l}\text { Errors in content still } \\
\text { remain. Essay is not } \\
\text { consistently clear. It may } \\
\text { not comply with } \\
\text { presentation requirements. } \\
\text { Chorale example and/or } \\
\text { repertoire excerpt may not } \\
\text { meet requirements. }\end{array}$ & $\begin{array}{l}\text { Essay is well organized and } \\
\text { clearly written. Some } \\
\text { problems still require } \\
\text { attention. }\end{array}$ & $\begin{array}{l}\text { Essay is well organized, } \\
\text { clearly written and } \\
\text { contains no errors. All } \\
\text { content and } \\
\text { presentation } \\
\text { requirements meet } \\
\text { expectations. Essay is } \\
\text { ready for publication. }\end{array}$ & & \\
\hline $\begin{array}{l}\text { Chorale-style } \\
\text { music example in } \\
\text { final version of } \\
\text { essay }\end{array}$ & $\begin{array}{l}\text { Not submitted } \\
\text { for } \\
\text { assessment. }\end{array}$ & $\begin{array}{l}\text { Example is inadequate, } \\
\text { contains many errors } \\
\text { and/or is not explained. It } \\
\text { does not support the essay } \\
\text { and/or does not comply } \\
\text { with requirements. }\end{array}$ & $\begin{array}{l}\text { Example is appropriate, but } \\
\text { contains errors or is poorly } \\
\text { explained. Presentation } \\
\text { may not meet } \\
\text { requirements. }\end{array}$ & $\begin{array}{l}\text { Example is mostly well } \\
\text { done, but may not be } \\
\text { presented neatly or } \\
\text { explanations may lack } \\
\text { clarity. }\end{array}$ & $\begin{array}{l}\text { Example contains no } \\
\text { errors, is explained } \\
\text { clearly and complies } \\
\text { with requirements. }\end{array}$ & & \\
\hline $\begin{array}{l}\text { Repertoire } \\
\text { excerpt in final } \\
\text { version of essay }\end{array}$ & $\begin{array}{l}\text { Not submitted } \\
\text { for } \\
\text { assessment. }\end{array}$ & $\begin{array}{l}\text { Does not feature a } \\
\text { modulation to a closely- } \\
\text { related tonality. Musical } \\
\text { context is not explained. } \\
\text { The excerpt does not } \\
\text { support the essay. }\end{array}$ & $\begin{array}{l}\text { Features a modulation, but } \\
\text { its musical context is } \\
\text { misunderstood. } \\
\text { Presentation is sloppy or } \\
\text { messy. }\end{array}$ & $\begin{array}{l}\text { Is a good example from the } \\
\text { repertoire that features a } \\
\text { modulation to a closely- } \\
\text { related tonality. Its musical } \\
\text { context may not be } \\
\text { explained well. } \\
\text { Presentation is reasonable. }\end{array}$ & $\begin{array}{l}\text { Is an excellent example } \\
\text { from the repertoire that } \\
\text { supports the essay. Its } \\
\text { context is clearly } \\
\text { explained. Presentation } \\
\text { is excellent. }\end{array}$ & & \\
\hline $\begin{array}{l}\text { Understanding of } \\
\text { modulation to } \\
\text { closely-related } \\
\text { tonalities }\end{array}$ & $\begin{array}{l}\text { No } \\
\text { understanding } \\
\text { of this topic is } \\
\text { evident. }\end{array}$ & $\begin{array}{l}\text { Project shows limited } \\
\text { understanding of this topic. }\end{array}$ & $\begin{array}{l}\text { Project indicates that about } \\
\text { half of the information } \\
\text { regarding modulation has } \\
\text { been understood. Errors in } \\
\text { comprehension are } \\
\text { apparent or much required } \\
\text { information is missing. }\end{array}$ & $\begin{array}{l}\text { Project demonstrates that } \\
\text { modulation is understood } \\
\text { reasonably well. Some } \\
\text { required information may } \\
\text { be missing. }\end{array}$ & $\begin{array}{l}\text { Project shows a } \\
\text { thorough understanding } \\
\text { of modulataion to } \\
\text { closely-related } \\
\text { tonalities. All required } \\
\text { information is included. }\end{array}$ & & \\
\hline $\begin{array}{l}\text { Author's } \\
\text { reflections }\end{array}$ & $\begin{array}{l}\text { Not } \\
\text { submitted. }\end{array}$ & Displays very little thought. & $\begin{array}{l}\text { Some critical thinking is } \\
\text { apparent. }\end{array}$ & $\begin{array}{l}\text { Demonstrates a good effort } \\
\text { to learn from the } \\
\text { experience of creating } \\
\text { Project } 1 .\end{array}$ & $\begin{array}{l}\text { Very perceptive and } \\
\text { illuminating comments. }\end{array}$ & & N/A \\
\hline $\begin{array}{l}\text { Editor's } \\
\text { reflections }\end{array}$ & $\begin{array}{l}\text { Not } \\
\text { submitted. }\end{array}$ & Displays very little thought. & $\begin{array}{l}\text { Some critical thinking is } \\
\text { apparent. }\end{array}$ & $\begin{array}{l}\text { Demonstrates a good effort } \\
\text { to learn from the } \\
\text { experience of creating } \\
\text { Project } 1 .\end{array}$ & $\begin{array}{l}\text { Very perceptive and } \\
\text { illuminating comments. }\end{array}$ & $\mathrm{N} / \mathrm{A}$ & \\
\hline $\begin{array}{l}\text { Total } \\
\text { Score: }\end{array}$ & & & & & & $/ 28$ & $/ 28$ \\
\hline
\end{tabular}




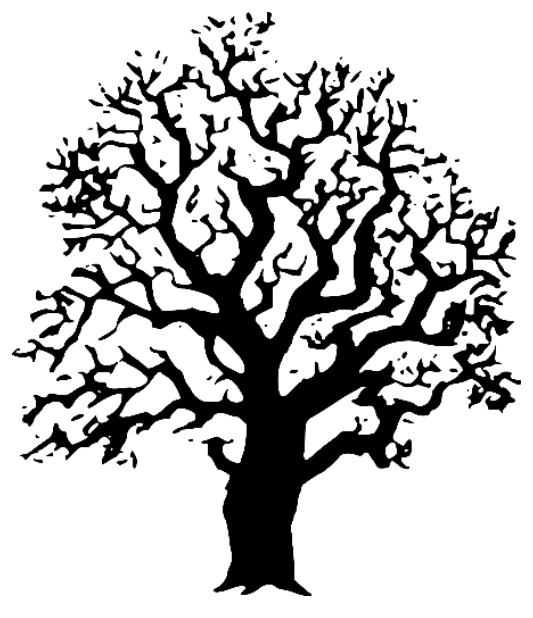

